\title{
MGNREGA and Economic Empowerment of Women - Study of Indian Women
}

\author{
Shivani Mehta* and Shalini Singh Sharma \\ Amity School of Economics, AUUP. Noida, Uttar Pradesh, India \\ *Corresponding author: smehta4@amity.edu
}

\begin{abstract}
Mahatma Gandhi National Rural Employment Guarantee Act (MGNREGA) was enacted in India in 2005. It guarantees 100 days of work and ensures at least 33 per cent of the women participation. Even though MGNREGA has played a substantial role in economically empowering women, it faces major challenges that restrict their participation. This essay dwells into the complexities faced by women in India and exposes various factors that limit the success of MGNREGA. The study finds that tenacious social norms, continued illegal presence of contractors, lack of proper childcare facilities and delayed payments are the crucial factors that restrict women participation. Policy implications for Indian Government are also put forward.
\end{abstract}

Keywords: MGNREGA, Women empowerment, Indian women, employment

India is one of the fastest developing countries of the world and is equally endowed with vast natural as well as human resources. It has a huge demographic dividend out of the 1.2 billion population. But inequality in terms of resource distribution and later inequality of income has grabbed India with many economic and social issues. MGNREGA is a job guarantee scheme basically for rural Indians enacted by legislation on $25^{\text {th }}$ August, 2005. In India where majority of the population lives below the poverty line MGNREGA was introduced with the aim of providing better job opportunities and hence improved purchasing power to people in rural India.

MGNREGA aims at enhancing the livelihood security of people in rural areas by guaranteeing hundred days of wage-employment in a financial year to a rural household whose adult members volunteer to do unskilled manual work. Around one-third of the stipulated work force is women. The law was initially called the National Rural Employment Guarantee Act (NREGA) and was renamed with the prefix "Mahatma Gandhi" on $2^{\text {nd }}$ October 2009, Gandhi's birth anniversary. Many economists debate that even though introduced on a very large scale MGNREGA has by and large been ineffective in reducing poverty across the Indian economy. Despite its best intentions, MGNREGA has contributed towards augmenting corruption across rural India, created poor quality of infrastructure and inflation. On the other hand this program also has its own merits. MNREGA (then known as NREGA) was launched on $2^{\text {nd }}$ February 2006 from Anantapur in Andhra Pradesh and initially covered 200 of the "poorest" districts of the country. The Act was implemented in phases; 130 districts were added from 2007 to 2008. With its spread to over 626 districts across the country, the flagship program of the UPA government aimed at increasing the job opportunities, reducing distress migration and aiding the development of useful assets across Indian economy. In 2010-11, 41 million households were employed on NREGA worksites. This helped improve gender equality by including around $40 \%$ workers from across different backward classes and around 50\% women.

MGNREGA (then known as NREGA) started with an initial outlay of $\$ 2.5$ billion ( $₹ 113$ billion) in 
year 2006-07. The funding has considerably been increased under MGNREGA from \$2.5 billion in 2006-07 to $\$ 8.91$ billion in 2010-11. The government has been increasing fund under this flagship program because it is an important step to empower women by making them financially independent and adding to the rural prosperity. It has inculcated a sense of security among the weaker section as government is bound to provide them with hundred days of employment. There has been immense increase in the formal registration of people and also people demanding jobs under this scheme are increasing manifold. The data below gives a broader picture of the scheme.

Kerala and Tamil Nadu have taken a march over other states on the number of women participation followed by Rajasthan and Chhattisgarh. As per statistics with the Ministry, women constituted $85.05 \%$ of the total $3,16,287$ households which were provided jobs under the Rural Employment Guarantee Act since 2008. In Tamil Nadu, the percentage of women stood at 80.52 among a total of $21,21,317$ households employed under the Act. Among the western states, Rajasthan had the highest number of women who took up jobs under NREGA. They constituted $71.32 \%$ of the total 47,37,819 households which were provided work under the Act. Participation of women, however, remained lowest in Jammu and Kashmir during the said period. Of a total 55,176 employed in the state, the percentage of women stood merely at 4.22. So, this program is acting as a major breakthrough for women employment, building infrastructure and indirectly it is hitting of poverty issue as well. It guarantees 100 days of work and ensures at least 33 percent of the women participation. Even though MGNREGA has played a substantial role in economically empowering women, it faces major challenges that restrict their participation. This essay dwells into the complexities faced by women in India and exposes various factors that limit the success of MGNREGA. Having developed a fair understanding of the programme introduced by the Indian Government, section 2 details how MNREGA has helped women in India over the years. Section 3 then elaborates how tenacious social norms continued illegal presence of contractors, lack of proper childcare facilities and delayed payments are the crucial factors that still restrict women participation under this scheme which ultimately limits its success. Finally some policy implications for Indian Government are also put forward in the study.

\section{Increasing Participation of Women Through MGNREGA}

MGNREGA includes design features to tackle the challenges women face in the rural economy across India. It promotes their participation in the workforce through a one-third quota in each state, and gives preference to women (especially single women) to work close to home (Ministry of Rural Development, 2008). MGNREGA ensures that equal wages are paid to men and women under the provisions of the Equal Remuneration Act 1976 - an important measure given prevailing gender wage disparities. Guidelines under the act suggest that when banks and local governments open new account they should consider opening joint accounts in order to avoid crediting earnings solely to the male head of household. The Act states that women should play a major role in decision making activities and therefore should be given an opportunity to have higher representation in local level committees as well as state- and central-level councils.

As per Reetika Khera and Nayak, large interstate variations in the participation of women have been observed. Women constitute more than two thirds of MNREGA workers in Kerala (71\%), Rajasthan $(69 \%)$ and Tamilnadu (82\%) and less than stipulated one-third in Assam (31\%), Bihar (27\%), W.B (17\%), UP (15\%), Himachal Pradesh (30\%) and Jarkhand $(27 \%)$. They also show that the full potential of this Act is far from being realized. Two thirds of the female respondents reported having to face less hunger as a result of MNREGA employment. Overall, MNREGA was considered very important by $68 \%$ of the respondents. At majority worksites childcare facilities were lacking. MNREGA allowed workers to get work in their village, as a result of which scale of migration and hazardous works now reduced for many.

Even though the work done under MGNREGA has been applauded by policy makers over the years, the success of the act has been curtailed to a large extend. Various economists assert that tenacious social norms, continued illegal presence 
Table 1: Data for formal registration of people and people demanding jobs under MGNEREGA

\begin{tabular}{cccc}
\hline Year & $\begin{array}{c}\text { Cumulative number of } \\
\text { households issued job cards }\end{array}$ & $\begin{array}{c}\text { No. of households who have } \\
\text { demanded employment }\end{array}$ & Person days In Lakhs Women \\
\hline $2006-07$ & 37850390 & 21188894 & 3679.01 \\
$2007-08$ & 64740595 & 34326563 & 6109.10 \\
$2008-09$ & 100145950 & 45516341 & 10357.27 \\
$2009-10$ & 112548976 & 52920154 & 13640.49 \\
$2010-11(\mathrm{P})$ & 119561881 & 55801571 & 12236.30 \\
$2011-12(\mathrm{P})$ & 123876349 & 50911403 & 10380.76 \\
\hline
\end{tabular}

Source: $h$ ttp://data.gov.in/dataset-export-tool?nid=6183.

of contractors, lack of proper childcare facilities and delayed payments are the crucial factors that still restrict women participation under this scheme. The next section therefore details all such factors that restrict the participation of rural Indian women thereby restricting the success of the act.

\section{Factors Hampering Participation of Women in Rural Areas Under NREGA}

India's star programme MGNREGA has undoubtedly raised the bar for rural women who now work outside their homes and enjoy an equal status with their fellow workers. However there still exist social hurdles that make this act less women friendly in India. The battle of Indian women to be full participants under this scheme goes beyond being able to get their names on the job cards and getting work. These crucial limiting factors are detailed under.

Women dominate the workforce under the NREGA Scheme and hence major portion of the income generated through this scheme accrues to female workers. The introduction of wage payments through banks is one of the new challenges that the rural women face in India. While a single account is opened per job card, the account is generally opened in name of the male member of the house. As a result the autonomy of women to spend their own wages is greatly restricted as they have to rely on men to withdraw money. A survey conducted reported that all women contacted in Rajasthan has a bank or post office account in their own name where the wages were deposited; only 38 per cent of them could take decisions with regards to its spending (Ratna M. Sudarshan, 2011).

It is true that MGNREGA has not only provided employment opportunities to women who previously had no source of employment in rural areas but has also given more lucrative employment option to women engaged in agricultural works. Where in some cases the scheme has enhanced economic status and empowered women in certain households, in other cases it has negatively impacted the gender relations. Women's employment has aggravated stress and tension in many households. This is mainly because the opportunity cost of employment opportunities i.e. the time for household work and responsibility is largely being jeopardised. Moreover, the facility of flexible working hours for women to reduce this pressure of working hours was found missing in the scheme (Holmes et al. 2011).

Another major factor that restricts the success of MGNREGA is the illegal presence of contractors. The prevalence of contractors at the worksite is considered to be illegal under this scheme. This is because the presence of these contractors on worksite limits the employment opportunities for women workers seeking job. The contractors refrain from offering work to women since latter is considered to be physically weak and fragile. Women receive fewer days work because they are often assigned 'soft' work, such as moving soil dug out of wells, which requires less time (Holmes et al. 2011). Evidence has been reported in the state of Madhya Pradesh and Sabarkantha district of Gujarat where work was found to be offered to the young physically sound men (Pradhan, 2012). Furthermore, delay in payments hugely restricts female participation which in more acute in case of single women (Reetika Khera, 2011). Women who make their families' ends meet single handed cannot afford to wait for the payments from work. As a result they move back to their previous low earning employment activities. 
Although the NREGA clearly requires the arrangement of child care facility; ill and non-implementation of this feature affects the productivity of female workers especially the ones with breastfeeding infants. Most of the women do not bring their children to the worksite since they consider it unsafe. Keeping away from little ones for nearly eight hours keeps the women anxious as well as drain them emotionally. In a field survey in Rajasthan, it was reported that crèches were not available and children were left unattended (Ratna M. Sudarshan, 2011). Moreover, at a site it was noted that merely two cradles were made available amongst 180 workers.

The conservative beliefs and rigid societal norms against women working outside the home gravely hamper female inclusion under NREGA in rural India. Reportedly, women found it difficult to register under the scheme in the sates of Uttar Pradesh and Bihar since they were told that the programme is "not for them". Moreover, in case of excess of workers in Sitapur district of Uttar Pradesh, female workers are the first ones to turn down (Khera and Nayak, 2009).

Further, despite having high degree of awareness of their rights, women have little or no say in deciding the types of work to be carried out in the village. In fact social-cultural norms restrict them from participating in community meetings and social audits (Holmes et al. 2011).

\section{CONCLUSION}

On the basis of the study it can be clearly ascertained that the success of the MGNREGA has been curtailed to a large extend. Even though there is a universal consensus among the policy makers that the scheme has benefited the rural Indian population especially women, it is not wrong to assert that this success is limited to a large extend. The factors like tenacious social norms, continued illegal presence of contractors, lack of proper childcare facilities and delayed payments are the crucial factors that still restrict women participation under this scheme, limiting its success. The state should therefore work towards proper implementation of law and order along with other infrastructural development to ensure that the women who are restricted to the four boundaries of their homes, move out and enjoy the fruits of such a well-constructed scheme.

\section{REFERENCES}

Aakella, V. Karuna and Kidambi, Sowmya 2007. 'Challenging Corruption with Social Audits', Economic and Political Weekly, 3 February.

Aakella, V. Karuna and Kidambi Sowmya 2007. 'Social Audits in Andhra Pradesh: AProcess in Evaluation', Economic and Political Weekly, 24 November.

Abhay 2006. 'Status of National Rural Employment Guarantee Scheme in Raichur, (Karnataka)'. Satyagrah on 14-15 August 2007 at Raichur, Karnataka for NREGS'Acharya,

Acharya, Shankar 2005. 'Populism Rides Again', Business Standard, 27 December.

Adhikari, A. and Bhatia, K. 2010, 'NREGA Wage Payments: Can we Bank on Banks?', Economic and Political Weekly.

An Ecological Act: Abackgrounder to the National Employment Guarantee Scheme Environment, 'Findings of Social Audit of NREGS in Bharawan and Sandila Blocksof Hardoi District in U.P. During $25^{\text {th }}$ November - $2^{\text {nd }}$ December'Asha Parivar (2007),

Aruna 2005. 'Political and Administrative Realities of the EGS', Economic and Political Weekly, 15 October.

Banerjee, Kaustav and Saha, Partha 2010. 'The NREGA, the Maoists and the development woes of Indian State', Ecocnomic and Political Weekly, 10 July.

Barret, B.C., Holden, S. and Clay, D.C. 2002. 'Can Food-ForWork Programme Reduce Vulnerability?', Discussion Paper 2002/24, World Institute for Development Economics Research, Helsinki. Baruah,

Centre for Budget and Governance Accountability 2006. 'Draft Report on Implementation of NREGA in Andhra Pradesh, Chhattisgarh, Jharkhand and Madhya Pradesh'.

Debarchana, 'Assam Report on NREGA", mimeo,??' Benbabbaali, Dalel,'Implementation of the National Rural Employment Guarantee Act in atribal state: Meghalaya'.

Holmes, R., Sadana, N. and Rath, S. 2011. “An opportunity for change? Gender analysis of the Mahatma Gandhi National Rural Employment Guarantee Act", Project Briefing No 53, Overseas Development Institute, U.K.

Holmes, R., Sadana, N. and Rath, S. 2011. "An opportunity for change? Gender analysis of the Mahatma Gandhi National Rural Employment Guarantee Act", Project Briefing No 53, Overseas Development Institute, U.K.

January. Aiyar, Yamini and Samji, Salimah 2006. 'Improving the Effectiveness of National Rural Employment Guarantee Act', Economic and Political Weekly, 28 January.

Khera, R. and Nayak, N. 2009. “Women Workers and Perceptions of the National Rural Employment Guarantee Act", Economic and Political Weekly, pp. 49-57

Pradhan, S.K. 2012. "The NREGA and Rural Women: Employment Opportunities and Challenges", for international conference on: 'Inclusive and Sustainable Growth (Role of Industries, Government and Civil Societies)', organized by IMT and BAIF, 4-6 October 2012. 
Ratna M.Sudarshan 2011. “India's National Rural Employment Guarantee Act: Women's participation and impacts in Himachal Pradesh, Kerala and Rajasthan", CSP Research Report 06.

Ratna M. Sudarshan 2011. “India's National Rural Employment Guarantee Act: Women's participation and impacts in Himachal Pradesh, Kerala and Rajasthan", CSP Research Report 06.

Reetika Khera, Nayak Nandini 2009. “Women Workers Perceptions of the NREGA", Economic \& Political Weekly, October 24-30, XLIV(43): 49.
Report New Delhi: Centre for Budget and Governance Accountability, May-June. Centre for Science and Environment.

Sankar 2004. 'Bad Ideas Are Winning', Business Standard, 28 December.

“The Battle of Employment Guarantee", edited by Reetika Khera, Oxford University Press, 2011. 
